\title{
Quantifying the contribution of juvenile migratory phenotypes in a population of Chinook salmon Oncorhynchus tshawytscha
}

\author{
Jessica A. Miller ${ }^{1, *}$, Ayesha Gray ${ }^{2}$, Joseph Merz ${ }^{3,4}$ \\ ${ }^{1}$ Coastal Oregon Marine Experiment Station, Hatfield Marine Science Center, Department of Fisheries and Wildlife, \\ Oregon State University, 2030 SE Marine Science Drive, Newport, Oregon 97365, USA \\ ${ }^{2}$ Cramer Fish Sciences, 2245 Clark St., North Bend, Oregon 97459, USA \\ ${ }^{3}$ Institute of Marine Sciences, University of California Santa Cruz, Santa Cruz, California 95064, USA \\ ${ }^{4}$ Cramer Fish Sciences, 636 Hedburg Way \#22, Oakdale, California 95361, USA
}

\begin{abstract}
Chinook salmon is an anadromous species that varies in size at freshwater emigration, which is hypothesized to increase population resiliency under variable environmental regimes. In California's Central Valley (USA), the majority of naturally spawned juveniles emigrate in 2 pulses: small juveniles (referred to as fry), typically $\leq 55 \mathrm{~mm}$ fork length (FL), emigrate from natal streams in February-March, whereas larger juveniles (smolts), typically $>75 \mathrm{~mm} \mathrm{FL,} \mathrm{emigrate} \mathrm{in} \mathrm{mid-April-}$ May. In some river systems, there is a smaller pulse of emigrants of intermediate size (parr), typically 56 to $75 \mathrm{~mm}$ FL. Although the relative contribution of these migratory phenotypes to the adult population is unknown, management activities focus on survival of larger emigrants and most artificially produced fish (98\%) are released from hatcheries at parr and smolt sizes. We reconstructed individual length at freshwater emigration for a sample of adult Central Valley Chinook salmon from 2 emigration years using chemical ( $\mathrm{Sr}: \mathrm{Ca}$ and $\mathrm{Ba}: \mathrm{Ca}$ ) and structural otolith analyses. The adult sample was comprised of individuals that emigrated as parr (mean $=48 \%$ ), followed by smolts $(32 \%)$ and fry $(20 \%)$. Fry-sized emigrants likely represent natural production because fish $\leq 55 \mathrm{~mm}$ FL comprise $<2 \%$ of the hatchery production. The distribution of migratory phenotypes represented in the adult sample was similar in both years despite apparent interannual variation in juvenile production, providing evidence for the contribution of diverse migratory phenotypes to the adult population. The contribution of all 3 migratory phenotypes to the adult population indicates that management and recovery efforts should focus on maintenance of life-history variation rather than the promotion of a particular phenotype.
\end{abstract}

KEY WORDS: Chinook salmon · Migratory phenotype $\cdot$ Otolith chemistry Resale or republication not permitted without written consent of the publishe

\section{INTRODUCTION}

Many diadromous fishes display variation in juvenile migratory behavior. Individuals with distinct migratory phenotypes may experience differential survival and thus contribute to a population's resiliency, defined as its ability to persist following disturbances across variable environmental conditions (Holling 1973, Stearns 1992, Hilborn et al. 2003, Secor 2007, Bottom et al. 2009). Chinook salmon Oncorhynchus tshawytscha is an anadromous species that displays extensive variation in the size at, and timing of, freshwater emigration (Taylor 1990, Healey 1991, Quinn 2005, Waples et al. 2009). However, limited empirical data on the contribution of distinct migratory phenotypes to adult populations across years prevents a robust evaluation of the resiliency hypothesis. Certain approaches, such as artificial tagging studies and scale analyses, can be used to determine the contribution of migratory phenotypes; however, each of these methods has substantial 
logistic and interpretive limitations. Chemical and structural analyses of fish otoliths, which hold a record of aspects of an individual's environment, provide an alternative approach to generating empirical data on the contribution of migratory phenotypes without the need to recapture individuals (Campana 1999, Campana \& Thorrold 2001).

Extensive agricultural land use conversion and water development within California's Central Valley (USA) (Fig. 1) have impacted the region's fall Chinook salmon (Moyle 2002), which are listed as a species of concern under the Endangered Species Act (Good et al. 2005). The majority of naturally spawned juveniles emigrate in 2 pulses: small juveniles (referred to as fry), typically $\leq 55 \mathrm{~mm}$ fork length (FL), emigrate from

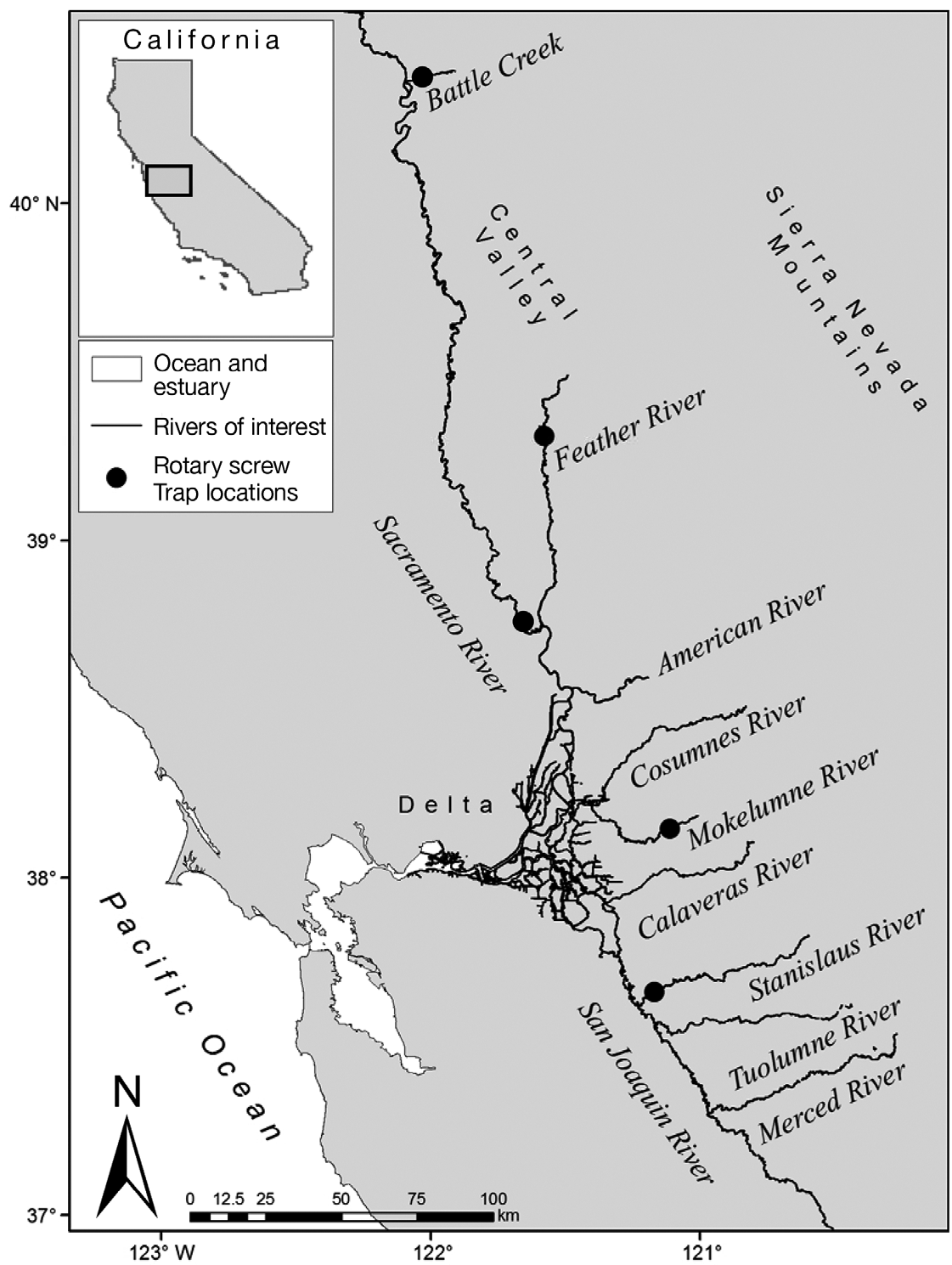

Fig. 1. General location of the Central Valley, California (inset). Major rivers, approximate rotary screw trap locations $(\bullet)$, and the Delta region are also identified natal streams in February-March, whereas larger juveniles (smolts), typically $>75 \mathrm{~mm} \mathrm{FL}$, emigrate in mid-April-May (Brandes \& McLain 2001) (Fig. 2a-f). In some river systems, there is a smaller pulse of emigrants of intermediate size (parr), typically 56 to $75 \mathrm{~mm}$ FL (Fig. 2g-h). The movement patterns of these emigrant size classes are not well described, but it has been suggested that individuals remain in freshwater portions of the Sacramento-San Joaquin River Delta until they attain sizes $>70 \mathrm{~mm} \mathrm{FL}$, at which point they enter the ocean (MacFarlane \& Norton 2002). Additionally, although there is no information on the relative survival of these emigrant size classes, water and hatchery management strategies within the Central Valley focus on maximizing survival of smolt-sized emigrants (Brandes \& McLain 2001, Williams 2001). For example, in-river flows are regulated to maximize survival during smolt emigration and $>50 \%$ of hatchery juveniles are released as smolts and $2 \%$ as fry.

Numerous studies have used otolith $\mathrm{Sr}: \mathrm{Ca}$ to reconstruct aspects of migratory history (e.g. Elsdon \& Gillanders 2006, Thibault et al. 2007, Volk et al. 2010) and $\mathrm{Sr}: \mathrm{Ca}$ and Ba:Ca have been combined to examine diadromous migrations (e.g. McCulloch et al. 2005, Bradbury et al. 2008, Crook et al. 2008, Milton et al. 2008). Such reconstructions are possible because otoliths grow continuously throughout the life of a fish and certain elements, such as Sr, are incorporated into an otolith in proportion to their water concentration. The ratio of $\mathrm{Sr}$ to $\mathrm{Ca}(\mathrm{Sr}: \mathrm{Ca})$ is typically greater in marine waters $\left(\sim 8.5 \mathrm{mmol} \mathrm{mol}^{-1}\right)$ than in freshwater $\left(<5 \mathrm{mmol} \mathrm{mol}^{-1}\right)$ although elevated values can occur in freshwater (Kraus \& Secor 2004, Brown \& Severin 2009). Therefore, variation in otolith $\mathrm{Sr}: \mathrm{Ca}$ is often used to reconstruct diadromous migrations (e.g. Limburg 1995, Secor et al. 1995, Daverat et al. 2005). However, the utility of using otolith $\mathrm{Sr}$ :Ca is limited; the reason being that $\mathrm{Sr}$ and $\mathrm{Ca}$ water concentrations vary linearly (conservatively) along a salinity gradient, while $\mathrm{Sr}$ :Ca ratios display a curvilinear relationship with salinity which results in minimal variation in $\mathrm{Sr}$ :Ca above salinities of $\sim 8$ to 10 (Kraus \& Secor 2004, Zimmerman 2005). Otolith Ba to Ca (Ba: Ca), which is also positively related to water $\mathrm{Ba}: \mathrm{Ca}$, may provide greater dis- 

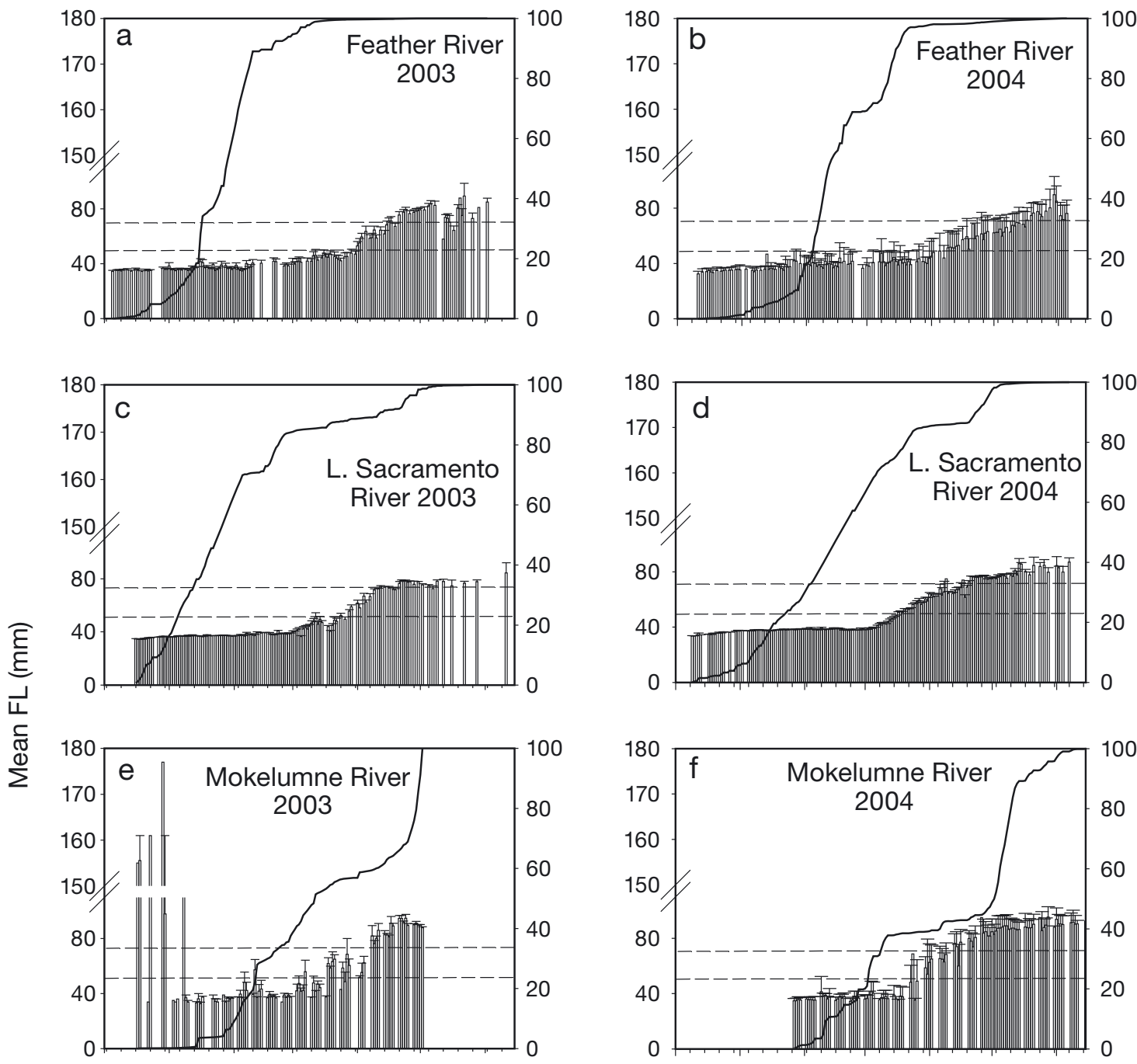

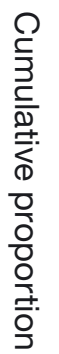
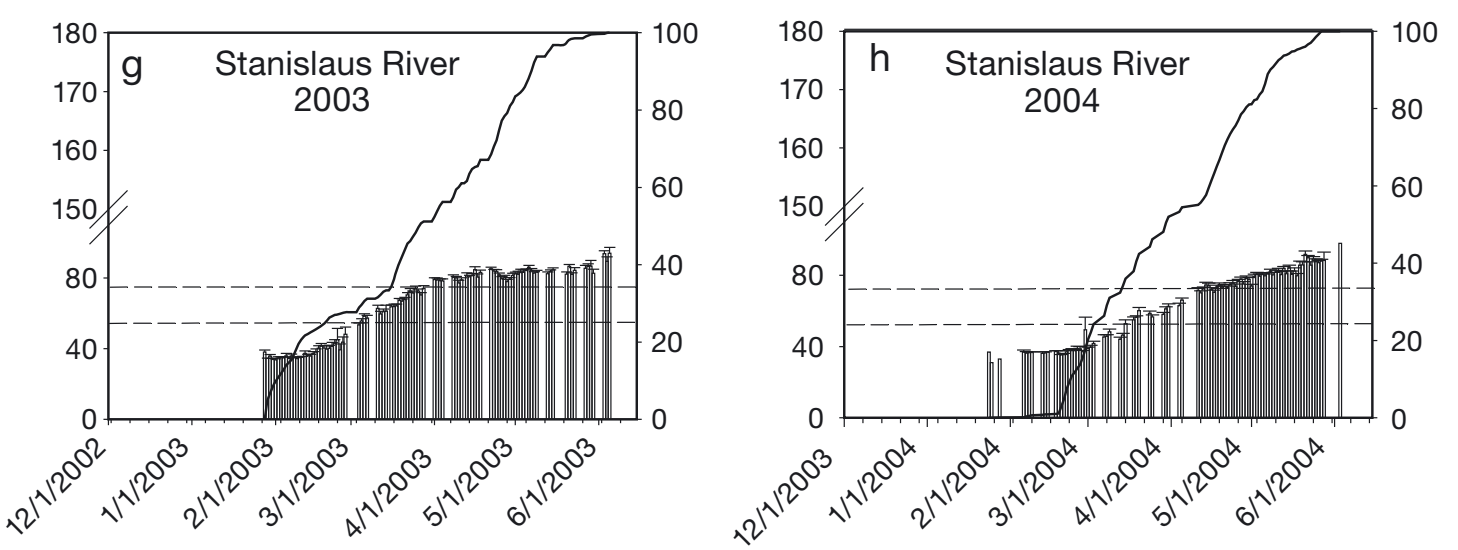

Date

Fig. 2. Oncorhynchus tshawytscha. Size and timing of juvenile Chinook salmon emigration in the Central Valley, California. Mean $( \pm \mathrm{SE}$ ) fork length (FL, mm; bars) and cumulative percent frequency of the total catch (solid line) are plotted against day of year (mo/d/yr). Data are from in-river rotary screw traps collections. In all cases, traps were placed in-river immediately prior to the first date with data presented. Data are included for 2003 and 2004 for (a,b) Feather River; (c,d) Lower Sacramento River; (e,f) Mokelumne River; and $(\mathrm{g}, \mathrm{h})$ Stanislaus River. Size designations for fry ( $\leq 55 \mathrm{~mm}$ FL), parr (56 to $75 \mathrm{~mm}$ FL), and smolt (>75 mm FL) are indicated by dashed lines 
crimination between estuarine and marine habitats because $\mathrm{Ba}: \mathrm{Ca}$ is often much greater $(>50 \times)$ in freshwater compared with marine waters (Elsdon \& Gillanders 2005, Hamer et al. 2006). Additionally, Ba displays non-conservative mixing behavior, which results in regions of enrichment at low salinities due to several processes, including desorption and resuspension (Coffey et al. 1997, Colbert \& McManus 2005). Otolith Sr:Ca and $\mathrm{Ba}$ :Ca may be more useful in combination when discriminating among freshwater, estuarine, and marine residence than either elemental ratio alone, and allow for more detailed reconstruction of migratory phenotypes.

Few studies have used otolith Sr:Ca to quantify the relative contribution of juvenile migratory phenotypes in an adult population (Limburg 2001, Kraus \& Secor 2004, Chino \& Arai 2009) and, to our knowledge, none have evaluated the combined potential of $\mathrm{Sr}: \mathrm{Ca}$ and $\mathrm{Ba}: \mathrm{Ca}$ in such an approach. The primary objective of the present study was to reconstruct the juvenile migratory phenotypes of adult Central Valley fall Chinook salmon using otolith elemental (Sr:Ca and $\mathrm{Ba}: \mathrm{Ca}$ ) and structural analysis and determine the proportion of each phenotype present in a sample of adults that emigrated in 2003 or 2004. Given that rates of otolith elemental incorporation can vary among species, with temperature and possibly with salinity (Campana 1999, Elsdon \& Gillanders 2003, Miller 2009), we developed species-specific models for the otolith incorporation of $\mathrm{Sr}: \mathrm{Ca}$ and $\mathrm{Ba}: \mathrm{Ca}$ to accomplish this objective. Furthermore, as noted by Elsdon et al. (2008), it is important to examine spatial patterns in water chemistry to confirm interpretations of otolith composition. Therefore, we also compiled data on water Sr:Ca and Ba:Ca throughout the Central Valley and coastal ocean. Finally, we obtained information on the relative abundance of migratory phenotypes observed in the juvenile emigrant population in 2003 and 2004 to compare with our adult reconstructions.

\section{MATERIALS AND METHODS}

Otolith incorporation of $\mathrm{Sr}$ and $\mathrm{Ba}$ in juvenile Chinook salmon. Species-specific models that describe the relationship between metal:calcium (Me:Ca) ratios of water and biogenic carbonates, such as those for corals and bivalves, are often used in palaeological and modern applications (e.g. Swart et al. 1999, Wei et al. 2000, Gaetani \& Cohen 2006). In these cases, the relationships between water and carbonate Me:Ca are quantified under controlled laboratory conditions, and those relationships are used to interpret variations observed in field-collected individuals. However, we are aware of only one study that developed a speciesspecific model of otolith elemental incorporation to address a specific ecological question (see Kraus \& Secor 2004). In previous studies, information from otoliths of other species were used to generate threshold levels indicative of habitat transitions for the species of interest (e.g. Hedger et al. 2008) or the species of interest was collected from representative locations to generate a baseline of otolith Me:Ca values (e.g. Daverat et al. 2005).

Here we developed models for the otolith incorporation of $\mathrm{Sr}$ and $\mathrm{Ba}$ in juvenile fall Chinook salmon using data on water and otolith $\mathrm{Sr}: \mathrm{Ca}$ and $\mathrm{Ba}$ :Ca that were collected from field collections and laboratory experiments. Data were included in models only if measurements of both water and otolith Me:Ca were available (Table 1). For water analyses, samples were collected, filtered $(0.45 \mu \mathrm{m})$, and acidified using standard methods (Eaton et al. 2005). Standard calibrations were generated with SPEX Certiprep ${ }^{\circledR}$ Group certified reference materials, and $\mathrm{Ca}, \mathrm{Sr}$, and $\mathrm{Ba}$ concentrations were measured with a Teledyne Leeman Prodigy inductively coupled plasma-optical emission spectrometer. Samples of known concentration (National Institute of Standards and Technology [NIST]; Standard

Table 1. Sources of juvenile Chinook salmon otoliths used to determine relationships between water and otolith Sr:Ca and water and otolith Ba:Ca. Mean water temperature $\left({ }^{\circ} \mathrm{C}\right)$, salinity, and $\mathrm{Sr}: \mathrm{Ca}$ and $\mathrm{Ba}: \mathrm{Ca}$ ratios associated with each source are included. n: number of juveniles included for each category; trt: salinity $\times$ water Me:Ca treatment combination; OR: Oregon; CV: Central Valley; CA: California; CLC: controlled laboratory conditions; nd: no data available

\begin{tabular}{|c|c|c|c|c|c|c|c|}
\hline \multirow{2}{*}{ Source of juveniles } & \multirow{2}{*}{ Date } & \multirow{2}{*}{$\begin{array}{c}\text { Water } \\
\text { temperature }\left({ }^{\circ} \mathrm{C}\right)\end{array}$} & \multirow{2}{*}{ Salinity } & \multicolumn{2}{|c|}{ - Water $\mathrm{Sr}: \mathrm{Ca}^{-}$} & \multicolumn{2}{|c|}{- Water Ba: $\mathrm{Ca}^{-}$} \\
\hline & & & & $\mathrm{mmol} \mathrm{mol}-1$ & $\mathrm{n}$ & $\mu \mathrm{mol} \mathrm{mol}{ }^{-1}$ & $\mathrm{n}$ \\
\hline Trask River hatchery, OR & Apr 2006 & nd & 0 & 2.6 & 9 & 84 & 8 \\
\hline Merced River hatchery, CV & Feb 2008 & nd & 0 & 3.4 & 11 & 1600 & 7 \\
\hline Mokelumne River hatchery, CV & Feb 2008 & nd & 0 & 5.1 & 7 & 1100 & 11 \\
\hline $\begin{array}{l}\text { Coastal ocean, Southern OR, } \\
\text { Northern CA }\end{array}$ & Jul 2008 & nd & 32 & 8.6 & 16 & 5 & 16 \\
\hline J. A. Miller (unpubl. data), CLC & nd & $8.8,11.9,15.3$ & $0,5,10,15$ & $\begin{array}{l}1.5,7.2 \\
7.8,8.2\end{array}$ & $\begin{array}{c}4-6 \\
\text { fish/trt }\end{array}$ & $\begin{array}{l}30,60,75,135 \\
230,520,1035\end{array}$ & $\begin{array}{c}4-6 \\
\text { fish/trt }\end{array}$ \\
\hline Zimmerman (2005), CLC & nd & $4.9-10.7$ & $\begin{array}{c}0,6.3,12.7 \\
18.6,15.5,33.0\end{array}$ & $\begin{array}{l}2.8,6.4,7.4 \\
7.7,7.9,8.4\end{array}$ & $\begin{array}{c}12 \\
\text { fish/trt }\end{array}$ & nd & nd \\
\hline
\end{tabular}


Reference Material 1643e) were introduced throughout the run to estimate accuracy: measured concentrations were within 2.0,1.3, and $2.4 \%$ of reported values for $\mathrm{Ca}, \mathrm{Sr}$, and $\mathrm{Ba}$, respectively ( $\mathrm{n}=7$ ). Precision was estimated with repeated measurements of the same sample (NIST 1643e) and varied by $<2.5 \%$ for all 3 elements $(n=3)$. For otolith analyses, sagittae were prepared using standard methods to minimize contamination (e.g. Miller 2009). Otolith ${ }^{43} \mathrm{Ca},{ }^{86} \mathrm{Sr}$, and ${ }^{138} \mathrm{Ba}$ data were collected using a VG PQ ExCell inductively coupled plasma mass spectrometer (ICPMS) with a New Wave DUV193 excimer laser. The laser was set at a pulse rate of $10 \mathrm{~Hz}$ with a $40 \mu \mathrm{m}$ diameter spot size and travelled at $5 \mu \mathrm{m} \mathrm{s}^{-1}$. Limits of detection (ppm) were calculated as 3 standard deviations of background measurements: $\mathrm{Ca}=0.02, \mathrm{Sr}=0.03$, and $\mathrm{Ba}=0.008$. Normalized ion ratios were converted to elemental ratios as described in Miller (2007), converted to molar ratios based on the molar mass of $\mathrm{Ca}, \mathrm{Sr}$, and $\mathrm{Ba}$, and presented as mmol mol${ }^{-1}$ for Sr:Ca and $\mu \mathrm{mol} \mathrm{mol}^{-1}$ for $\mathrm{Ba}$ :Ca. The mean percent relative standard deviations (\%RSD) for NIST 612 glass during data collection were ${ }^{43} \mathrm{Ca}=3.2,{ }^{86} \mathrm{Sr}=4.1$, and ${ }^{138} \mathrm{Ba}=4.4 \%$. A calcium carbonate standard of known composition developed by the US Geological Survey (USGS MACS-2) provided an estimate of accuracy: measured values were within $2 \%$ of known values for both $\mathrm{Sr}: \mathrm{Ca}$ and $\mathrm{Ba}: \mathrm{Ca}$. Linear and non-linear regression analyses were used to quantify the relationships between otolith and water $\mathrm{Me}: \mathrm{Ca}$ using Statistica ${ }^{\circledR}$. Data were examined for normality and homogeneity of variance prior to analysis.

Spatial patterns in water chemistry. In order to examine spatial patterns in water chemistry, we acquired existing data on $\mathrm{Ca}, \mathrm{Sr}$, and $\mathrm{Ba}$ water concentrations in coastal waters and within the Central Valley and collected additional samples from coastal areas and tributaries, including the Cosumnes, Mokelumne, Calaveras, Stanislaus, and San Joaquin Rivers (Fig. 1, Table A1 in Appendix 1). The purpose of this data collection effort was to provide an estimate of the variation in freshwater $\mathrm{Sr}: \mathrm{Ca}$ and Ba:Ca observed in the Central Valley and determine if there were freshwater systems with elevated Sr:Ca that could confound interpretation of migratory history based on adult otoliths. Water samples were collected and processed as described above. Samples of known concentration (NIST 1643e) were introduced throughout the run to estimate accuracy: measured concentrations were within $2.5,1.8$, and $2.6 \%$ of reported values for $\mathrm{Ca}, \mathrm{Sr}$, and $\mathrm{Ba}$, respectively $(n=3)$. Precision was estimated with repeated measurements of the same sample (NIST 1643e) and varied by $<3.2 \%$ for all 3 elements ( $n=3)$.

The relationships between water $\mathrm{Sr}: \mathrm{Ca}$ and $\mathrm{Ba}: \mathrm{Ca}$ and salinity ( 0 to 32 ) were predicted based on end member water concentrations similar to those observed in the Delta region, which is the downstream extent of freshwater in the Central Valley, and coastal waters. For our model, we assumed conservative mixing behavior for $\mathrm{Ca}, \mathrm{Sr}$, and $\mathrm{Ba}$. However, it is important to note that $\mathrm{Ba}$ often displays non-conservative mixing with regions of Ba release, due to desorption and resuspension, between salinities of 1 and 15 (Coffey et al. 1997). Therefore, our Ba:Ca model represents a minimum estimate for water $\mathrm{Ba}$ :Ca at low salinities. It is likely that at low salinities Ba:Ca ratios often exceed values predicted based on conservative mixing, particularly during periods of high freshwater discharge (Coffey et al. 1997, Colbert \& McManus 2005).

Back-calculation of juvenile size. The reconstruction of individual length at specific habitat transitions, such as freshwater emigration, based on otolith measurements requires an accurate back-calculation model. Therefore, we confirmed that otolith size provides a robust predictor of fall Chinook salmon size during the first year of life by collecting juveniles from several locations and brood years to quantify the relationship between fish and otolith size (Table 2). We measured juvenile FL $(0.5 \mathrm{~mm})$ prior to preservation, removed sagittal otoliths, and measured otolith width (OW, to the nearest $\mu \mathrm{m}$ ) along the dorsal-ventral growth axis at the widest point. There were no significant differences in OW between left and right sagittae $(n=50, p>0.40)$, and preliminary analysis indicated that OW was a better predictor of fish length than otolith length. All otolith distances were measured using a Leica ${ }^{\circledR}$ stereoscope and Image Pro Plus ${ }^{\circledR}$. A linear regression analysis of FL and OW was completed for all juveniles.

Application to Central Valley fall Chinook salmon. Adult Chinook salmon were collected during the Ore-

Table 2. Oncorhynchus tshawytscha. Source, year of collection, and size range of juvenile Chinook salmon used to develop the relationship between otolith and fish size. $\mathrm{n}$ : number of juveniles included for each category; $\mathrm{CV}$ : Central Valley; OR; Oregon

\begin{tabular}{|lccc|}
\hline Source & $\begin{array}{c}\text { Year } \\
\text { of collection }\end{array}$ & $\begin{array}{c}\text { Fork length } \\
(\mathrm{mm})\end{array}$ & $\mathrm{n}$ \\
\hline Mokelumne River hatchery, CV & 2008 & $40-48$ & 7 \\
Umpqua River hatchery, OR & 2007 & $40-94$ & 15 \\
Trask River hatchery, OR & 2007 & $43-88$ & 8 \\
Merced River hatchery, CV & 2008 & $51-83$ & 11 \\
Rogue River hatchery, OR & 2007 & $63-80$ & 9 \\
Coastal ocean, southern OR & $2006-2007$ & $84-125$ & 52 \\
Coastal ocean, off Columbia River & 1999,2000, & $98-166$ & 21 \\
& 2002,2006 & & \\
\hline
\end{tabular}


gon ocean troll fishery in 2006. Biological data, including FL $(\mathrm{cm})$, a tissue sample for genetic analysis, and several scales were collected from 2567 individuals. Otoliths were collected from a subset of those adults $(n=395)$. The region of origin for each individual was determined using a microsatellite DNA baseline, the Genetic Analysis of Pacific Salmonids, which identifies Central Valley fall Chinook salmon with a reported mean accuracy of $94.5 \%$ (Seeb et al. 2007). Fifty-nine percent of the fish were identified as Central Valley fall Chinook salmon. Only otoliths from fish identified as Central Valley fall Chinook salmon with $>90 \%$ posterior probability of assignment were included in remaining analyses $(n=100)$. Scales were used to determine individual age and, hence, year of emigration. Individual age was determined by counting winter annuli on scales. Each scale was read by 2 observers, and disagreements were resolved during a joint third reading. Scales from other Central Valley adult Chinook salmon of known age were available and included to provide a test of ageing accuracy $(n=31)$ : for these individuals, age was known due to the presence of coded wire tags (CWTs) (Jefferts et al. 1963).

Adult otoliths $(\mathrm{n}=100)$ were prepared as described in 'Materials and methods', 'Otolith incorporation of $\mathrm{Sr}$ and Ba in juvenile Chinook salmon', except that $52 \%$ were prepared as transverse and $48 \%$ as sagittal sections. We visually inspected all sections for proper orientation and exposure of the core primordia to ensure that data were collected along the same dorsal-ventral axis on all samples. For 9 individuals, we prepared one otolith as a transverse section and one as a sagittal section to compare the back-calculated size estimates generated with the 2 preparations. Otolith ${ }^{43} \mathrm{Ca},{ }^{86} \mathrm{Sr}$, and ${ }^{138} \mathrm{Ba}$ data were collected along transects that intersected the core region (Fig. 3) using methods similar to those described above. Limits of detection (ppm) were calculated as $3 \mathrm{SD}$ of background measurements: $\mathrm{Ca}=0.09, \mathrm{Sr}=0.09$, and $\mathrm{Ba}=0.007$. The mean \%RSDs for NIST 612 glass during data collection were ${ }^{43} \mathrm{Ca}=$ $3.0,{ }^{86} \mathrm{Sr}=4.4$, and ${ }^{138} \mathrm{Ba}=4.2 \%$. External estimates of accuracy based on USGS MACS-2 were within 3 and $2 \%$ of known values for $\mathrm{Sr}: \mathrm{Ca}$ and $\mathrm{Ba}: \mathrm{Ca}$, respectively.

We then combined otolith $\mathrm{Sr}: \mathrm{Ca}$ and Ba:Ca data and structural analysis to determine individual length at freshwater emigration. For each individual, the OW at the time of freshwater emigration was determined by the initial and abrupt increase in otolith $\mathrm{Sr}: \mathrm{Ca}$, which indicates exit from freshwater, prior to stabilizing at brackish/ocean values (Fig. 3). This transition was verified by the occurrence of low or declining otolith $\mathrm{Ba}: \mathrm{Ca}$ at the same time as the abrupt increase in otolith Sr:Ca. Threshold values for otolith Me:Ca during freshwater, brackish, and marine residence were determined based on our relationships between (1) otolith and water Me:Ca (see 'Results', 'Otolith incorporation of Sr and Ba in juvenile Chinook salmon') and (2) water Me:Ca and salinity (see 'Results', 'Spatial patterns in water chemistry'). Individual FL (mm) at freshwater emigration was estimated using the measurements of OW based on otolith $\mathrm{Sr}$ :Ca and $\mathrm{Ba}: \mathrm{Ca}$ and the linear relationship between FL and OW developed for juvenile fall Chinook salmon (see 'Results', 'Back-calculation of juvenile size'). Confidence intervals (95\% CI) for backcalculated size predictions were generated using standard methods $\left(\hat{\mathrm{Y}}_{i} \pm t_{0.05(2)} \times s_{\hat{Y} i}\right.$ Zar 1999).
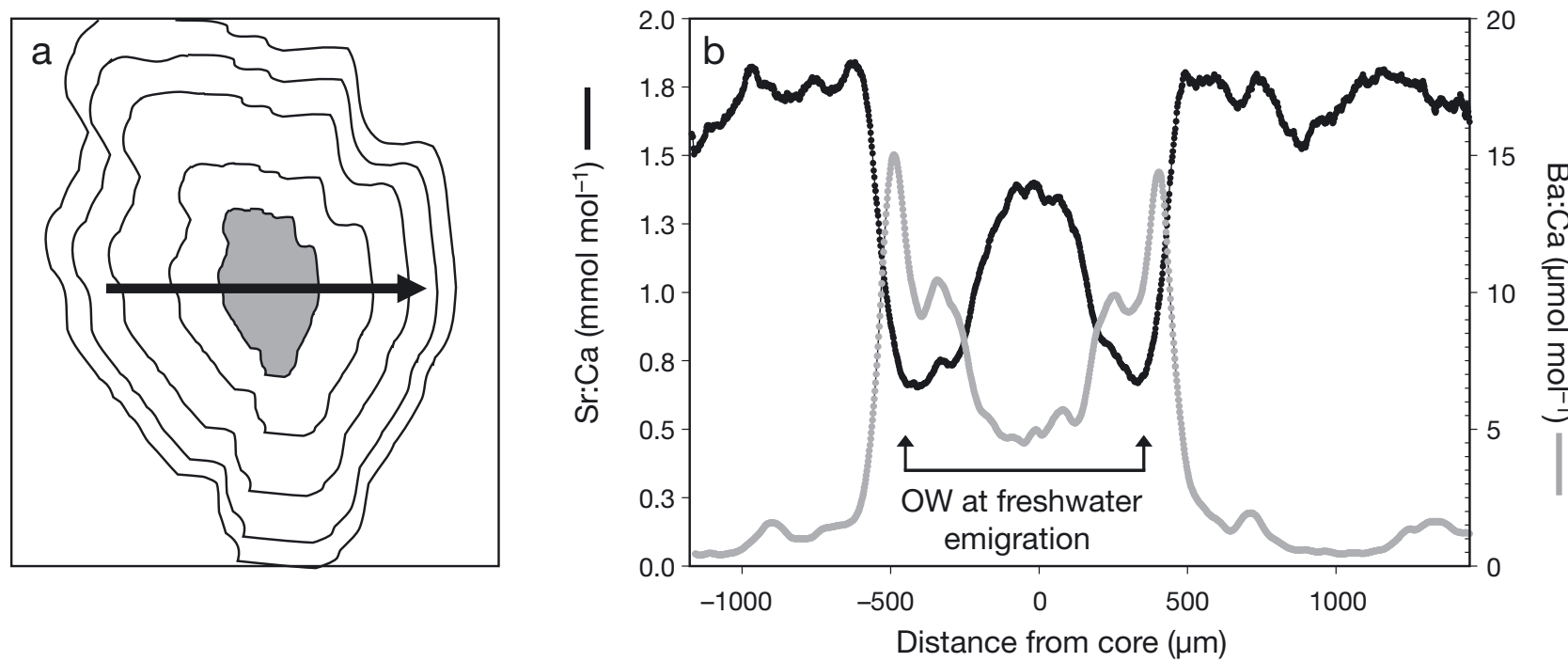

Fig. 3. Oncorhynchus tshawytscha. (a) Schematic of a sagittal section of an adult fall Chinook salmon otolith. Laser path for elemental analysis is identified. The core, which represents the egg and early juvenile life history, is shaded. (b) $\mathrm{Sr}: \mathrm{Ca}_{(\mathrm{mmol} \mathrm{mol}}^{-1}$ ) and $\mathrm{Ba}: \mathrm{Ca}\left(\mu \mathrm{mol} \mathrm{mol}{ }^{-1}\right)$ across the otolith. Measurement of otolith width $(\mathrm{OW})$ at freshwater emigration is identified 
Production of juvenile fall Chinook salmon. We would need comprehensive data on the relative abundance of the phenotypes present in natural and hatchery juvenile production in 2003 and 2004 to estimate survival rates for each phenotype based on our adult sample. However, there are no estimates for total natural production in the Central Valley basin. Therefore, we used data available from in-stream rotary screw traps to describe the size and relative abundance of naturally produced juveniles. We compiled daily information on size and number of individuals collected in traps on the lower Sacramento, Feather, Mokelumne, and Stanislaus Rivers (Fig. 1). The data from these 4 traps combined represent the size and relative abundance of $>70 \%$ of the natural production (Yoshiyama et al. 2000). All of these traps, except for the lower Sacramento River trap, are placed at river locations selected to maximize collection of naturally spawned emigrants. State hatcheries transport their production to estuarine waters for release so they would not be collected in-river. The only federal hatchery in the basin, i.e. the Coleman National Fish Hatchery on Battle Creek, releases juveniles in-stream and they could be collected in the lower Sacramento River trap. Additionally, estimates of total natural production upstream of a trap were available for the Feather and Mokelumne Rivers as well as a fifth trap on lower Battle Creek (Fig. 1). Trap data were obtained from the Bay Delta and Tributaries Project (http://bdat.ca.gov/) and R. Vincik, California Department of Fish and Game. For hatchery production, comprehensive data on the number and size of juveniles released in 2003 and 2004 are available from the Regional Mark Information System (www.rmpc.org/). Therefore, we compiled information on hatchery production from the 5

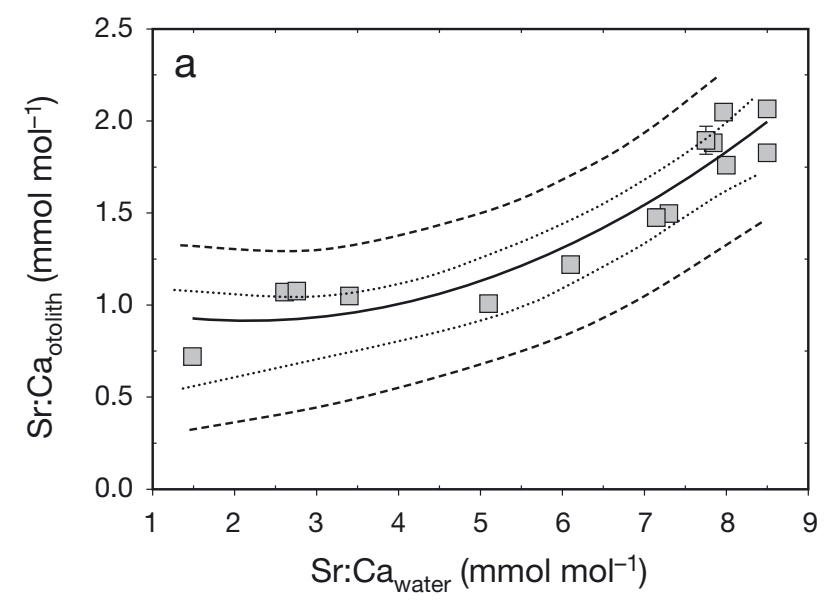

Central Valley hatcheries: the Coleman National Fish Hatchery and 4 state-run hatcheries, including the Nimbus, Feather River, Mokelumne River, and Merced River hatcheries. Release information is reported as fish $\mathrm{lb}^{-1}$; therefore, Piper et al. (1982) was used to convert mass to FL. We used the data collected from traps and hatchery records to generate (1) daily mean size estimates and cumulative percent frequencies for emigrants, and (2) size-frequency distributions for instream and hatchery production in 2003 and 2004 for comparison with our adult reconstructions of size at freshwater emigration.

\section{RESULTS}

\section{Otolith incorporation of $\mathrm{Sr}$ and Ba in juvenile Chinook salmon}

For Sr:Ca, data were available across a range of temperatures $\left(4.9\right.$ to $\left.15.3^{\circ} \mathrm{C}\right)$, salinities (0 to 33 ), and water $\mathrm{Sr}$ :Ca ratios (1.5 to $8.6 \mathrm{mmol} \mathrm{mol}^{-1}$ ) (Table 1). Otolith $\mathrm{Sr}: \mathrm{Ca}$ increased curvilinearly as water $\mathrm{Sr}: \mathrm{Ca}$ increased, and a polynomial regression provided the best fit to the data (Fig. 4a). For Ba:Ca, data were available across a range of temperatures (8.8 to $15.3^{\circ} \mathrm{C}$ ), salinities (0 to 32 ), and water $\mathrm{Ba}: \mathrm{Ca}$ ratios (5 to $1600 \mu \mathrm{mol} \mathrm{mol}^{-1}$ ) (Table 1). Otolith Ba:Ca also increased as water Ba:Ca increased, although in a linear manner; therefore, a linear model was used to describe the relationship (Fig. 4b). It appears that otolith Ba:Ca may have reached a plateau of $\sim 11 \mu \mathrm{mol} \mathrm{mol}^{-1}$ at water $\mathrm{Ba}$ :Ca ratios of $\sim 1100 \mu \mathrm{mol} \mathrm{mol}{ }^{-1}$; however, data from fish reared at higher levels of $\mathrm{Ba}$ :Ca would be needed to draw any firm conclusions. It is important to note

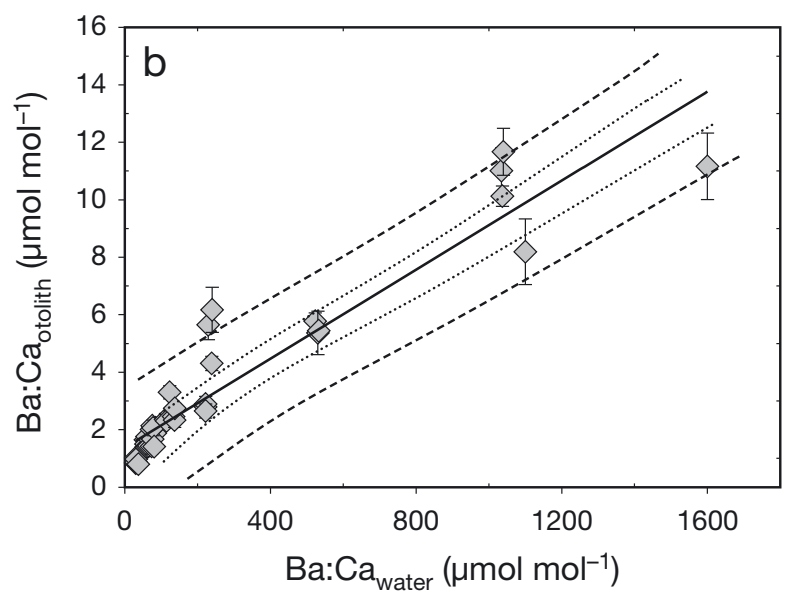

Fig. 4. Oncorhynchus tshawytscha. Relationships between otolith and water Sr:Ca and Ba:Ca. (a) Mean ( \pm 1 SE) otolith Sr:Ca versus water Sr:Ca $\left(\mathrm{mmol} \mathrm{mol}^{-1}\right)$. Curve (solid line) was fit by following relationship: $y=0.027( \pm 0.011 \mathrm{SE}) x^{2}-0.118( \pm 0.121 \mathrm{SE}) x+$ $1.043( \pm 0.266 \mathrm{SE})\left(\mathrm{p}<0.001, \mathrm{r}^{2}=0.89, \mathrm{n}=14\right)$. (b) Mean $( \pm 1 \mathrm{SE})$ otolith Ba:Ca versus water Ba:Ca $\left(\mu \mathrm{mol} \mathrm{mol}^{-1}\right)$. Curve (solid line) was fit by the following relationship: $y=0.008( \pm 0.0004 \mathrm{SE}) x+1.37( \pm 0.207 \mathrm{SE})\left(\mathrm{p}<0.001, \mathrm{r}^{2}=0.89\right.$, $\left.\mathrm{n}=38\right)$. Estimates for the $95 \%$ confidence (dotted line) and prediction (dashed line) intervals are included 
that although there were positive relationships between otolith and water $\mathrm{Me}$ :Ca ratios, the rate of incorporation declined as water $\mathrm{Me}: \mathrm{Ca}$ increased. For example, at water $\mathrm{Ba}: \mathrm{Ca}>1000 \mu \mathrm{mol} \mathrm{mol}{ }^{-1},<1 \%$ was incorporated into otoliths, whereas at water $\mathrm{Ba}: \mathrm{Ca}=$ $5 \mu \mathrm{mol} \mathrm{mol}{ }^{-1}, 32 \%$ was incorporated into otoliths.

\section{Spatial patterns in water chemistry}

Observed freshwater Me:Ca within the Central Valley ranged from 2.41 to $5.48 \mathrm{mmol} \mathrm{mol}^{-1}$ for $\mathrm{Sr}$ :Ca and from 141 to $1679 \mu \mathrm{mol} \mathrm{mol}{ }^{-1}$ for Ba:Ca (Table A1). Observed ocean Me:Ca averaged $( \pm \mathrm{SD}) \quad 8.55 \pm 0.33$ $\mathrm{mmol} \mathrm{mol}{ }^{-1}$ for Sr:Ca and $5.03 \pm 1.08 \mu \mathrm{mol} \mathrm{mol}{ }^{-1}$ for Ba:Ca. We used the empirically derived relationships between otolith and water Me:Ca (Fig. 4) to predict otolith $\mathrm{Me}$ :Ca ratios for juvenile Chinook salmon from the Central Valley (Table A1). We then compared predictions with observed otolith Me:Ca values, which were generated by averaging across $\sim 100 \mu \mathrm{m}$ of each adult otolith during presumptive freshwater and marine residence $(n=99)$. Note that one otolith was removed from analysis (see 'Results', 'Application to Central Valley fall Chinook salmon').

Predictions for otolith Sr:Ca during freshwater residence ranged from $0.91( \pm 0.1795 \% \mathrm{CI})$ to $1.20( \pm 0.09$ $95 \%$ CI) $\mathrm{mmol} \mathrm{mol}^{-1}$ (Table A1). The majority (85/99) of otolith Sr:Ca observations during presumed freshwater residence fell within the predicted $95 \%$ CI $(0.75$ to $1.29 \mathrm{mmol} \mathrm{mol}^{-1}$ ). Thirteen fish displayed otolith $\mathrm{Sr}: \mathrm{Ca}$ lower than predicted (i.e. 0.62 to $0.74 \mathrm{mmol} \mathrm{mol}^{-1}$ ) and one fish displayed otolith $\mathrm{Sr}$ :Ca higher than predicted $\left(1.31 \mathrm{mmol} \mathrm{mol}^{-1}\right)$. Our predictions for otolith $\mathrm{Ba} \mathrm{Ca}$ during freshwater residence ranged from $2.47( \pm 0.3595 \% \mathrm{CI})$ to $14.30 \quad( \pm 0.8895 \%$ CI $) \mu \mathrm{mol} \mathrm{mol}{ }^{-1}$ (Table A1). The majority (83/99) of observations of otolith Ba:Ca during presumed freshwater residence also fell within the predicted $95 \%$ CI (2.12 to $\left.15.18 \mu \mathrm{mol} \mathrm{mol}{ }^{-1}\right)$. Two fish displayed otolith Ba:Ca lower than predicted (i.e. 1.78 to $2.10 \mu \mathrm{mol} \mathrm{mol}{ }^{-1}$ ) and 14 fish displayed otolith $\mathrm{Ba}$ :Ca higher than predicted (15.40 to $32.28 \mu \mathrm{mol} \mathrm{mol}{ }^{-1}$ ). For otolith Me:Ca during ocean residence, observed values tended to be lower than predicted. Observed otolith Sr:Ca during ocean residence ranged from 1.50 to $2.20 \mathrm{mmol}$ $\mathrm{mol}^{-1}$ and $44 \%$ of the observations fell with the predicted range $(2.01 \pm 0.1395 \% \mathrm{CI})$; the remaining observations were all less than predicted. Observed otolith $\mathrm{Ba}: \mathrm{Ca}$ during ocean residence ranged from 0.35 to
$1.31 \mu \mathrm{mol} \mathrm{mol}{ }^{-1}$ and $12 \%$ of the observations fell with the predicted range $(1.40 \pm 0.4095 \% \mathrm{CI})$; the remaining observations were all less than predicted. There was no overlap in the mean otolith Me:Ca ratios observed during presumed freshwater and marine residence.

We generated predictions for water $\mathrm{Sr}: \mathrm{Ca}$ and $\mathrm{Ba}: \mathrm{Ca}$ from salinities of 0 to 32 based on end member water Me:Ca values similar to those observed in the Delta region and coastal waters (Fig. 5). Based on predicted and observed values, residence in freshwater (with $\mathrm{Sr}: \mathrm{Ca}<7 \mathrm{mmol} \mathrm{mol}^{-1}$ and $\mathrm{Ba}: \mathrm{Ca}>80 \mu \mathrm{mol} \mathrm{mol}{ }^{-1}$ ) would result in otolith signatures distinct from residence in marine waters (with $\mathrm{Sr}: \mathrm{Ca}>7.0 \mathrm{mmol} \mathrm{mol}^{-1}$ and $\mathrm{Ba}: \mathrm{Ca}<80 \mathrm{mmol} \mathrm{mol}^{-1}$; Fig. 5, Table A1). Given the predicted water Me:Ca ratios within the Central Valley, otolith Me:Ca ratios would not be distinct at salinities $>3$ for $\mathrm{Sr}$ : Ca and > 6 for Ba:Ca. (Fig. 5). However, as noted, Ba release commonly occurs in low salinity waters. If localized enrichment of Ba occurs in low salinity waters and results in $\mathrm{Ba}: \mathrm{Ca}>80 \mu \mathrm{mol} \mathrm{mol}{ }^{-1}$ while $\mathrm{Sr}$ :Ca remains greater than freshwater values $\left(>7.0 \mathrm{mmol} \mathrm{mol}^{-1}\right)$, otolith signatures of fish residing in those waters would be distinct from freshwater or marine signatures. Based on these predictions and observations, otolith $\mathrm{Sr}: \mathrm{Ca}<1.5 \mathrm{mmol} \mathrm{mol}^{-1}$ with $\mathrm{Ba}: \mathrm{Ca}>$ $2 \mu \mathrm{mol} \mathrm{mol}{ }^{-1}$ indicates freshwater residence, otolith $\mathrm{Sr}: \mathrm{Ca} \geq 1.5 \mathrm{mmol} \mathrm{mol}^{-1}$ with Ba:Ca $>2 \mu \mathrm{mol} \mathrm{mol}{ }^{-1}$ indicates brackish residence, and otolith $\mathrm{Sr}: \mathrm{Ca} \geq 1.5 \mathrm{mmol}$ $\mathrm{mol}^{-1}$ with $\mathrm{Ba}: \mathrm{Ca}<2 \mu \mathrm{mol} \mathrm{mol}{ }^{-1}$ indicates brackish/ ocean residence.

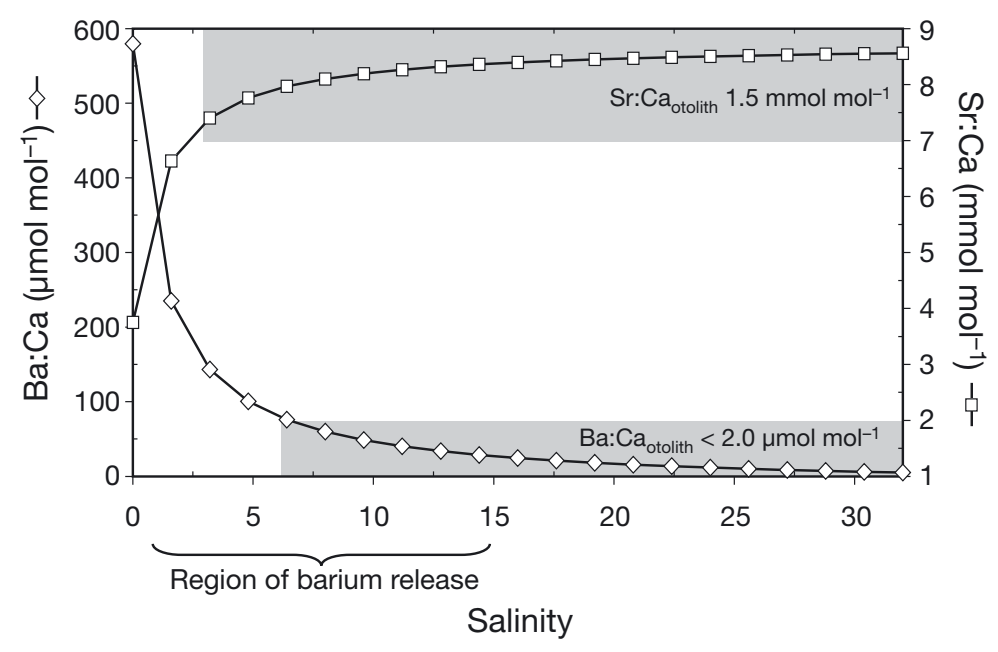

Fig. 5. Predicted relationship between water Ba:Ca and $\mathrm{Sr}: \mathrm{Ca}$ and salinity. Freshwater values (salinity $=0$ ) are within the range observed in the Central Valley Delta region. Shaded boxes indicate the water Me:Ca and salinities at which there would be minimal variation in otolith $\mathrm{Me}$ :Ca. Predicted values for otolith $\mathrm{Ba}: \mathrm{Ca}$ and $\mathrm{Sr}: \mathrm{Ca}$ at those water $\mathrm{Me}: \mathrm{Ca}$ ratios and salinities are included in shaded boxes. Predictions were based on observed relationship between otolith and water $\mathrm{Me}: \mathrm{Ca}$, measured water $\mathrm{Me}: \mathrm{Ca}$, and the assumption of conservative mixing behavior 


\section{Back-calculation of juvenile size}

For juveniles, FL (mm) was positively and linearly related to OW $(\mu \mathrm{m})\left(\mathrm{r}^{2}=0.93, \mathrm{n}=123, \mathrm{p}<0.001\right)$. Therefore, we used the following relationship to estimate FL based on OW:

$$
\mathrm{FL}=0.060( \pm 0.002 \mathrm{SE}) \times \mathrm{OW}+6.91( \pm 2.19 \mathrm{SE})
$$

Fish were grouped into $10 \mathrm{~mm}$ bins based on backcalculated size at freshwater emigration.

\section{Application to Central Valley fall Chinook salmon}

Adult Chinook salmon ranged in size from 66 to 102 cm FL at capture, and their scales displayed 2 or 3 winter annuli except for one fish with 4 winter annuli. As the fish with 4 annuli was the only individual that emigrated in 2002, it was removed from the analysis. Therefore, all individuals included hereafter emigrated in $2003(\mathrm{n}=49)$ or $2004(\mathrm{n}=50)$. All the 31 known-age, CWT-fish were correctly aged (= $100 \%$ accuracy). There was no systematic difference in backcalculated size estimates (paired $t$-test, $\mathrm{df}=9, \mathrm{p}=0.46$ ) between transverse and sagittal sections and the mean difference in back-calculated size was $<5 \%$.

Overall, estimated length at freshwater emigration ranged from 33 to $104 \mathrm{~mm}$ FL. The error (95\% CI) associated with individual back-calculations ranged from 2.3 to $10.7 \%$ and averaged $3.0 \%$. Parr-sized individuals comprised the largest emigrant group in both 2003 and 2004 (mean \pm SD across years $=47.5 \pm 0.8 \%$ ), followed by smolts $(32.4 \pm 6.2 \%)$, and fry $(20.1 \pm 5.4 \%$; Fig. 6a). For 18 individuals, the transition from fresh to marine waters included a period during which otolith $\mathrm{Sr}$ :Ca was $>1.5 \mathrm{mmol} \mathrm{mol}^{-1}$ and $\mathrm{Ba}$ :Ca was $>2 \mu \mathrm{mol}$ $\mathrm{mol}^{-1}$, which is predicted to represent residence in brackish waters. Of the 18 individuals with this brackish otolith signature, 11 were fry, 6 were parr, and 1 was a smolt.

\section{Juvenile production}

Over 36 million fall Chinook salmon were released from state and federal hatcheries in 2003 and more than 27 million were released in 2004 (Fig. 6b). The majority of juveniles were released as smolts (54 to $65 \%$ ), followed by parr (35 to $45 \%$ ), with less than $2 \%$ released as fry. The majority of juveniles (>75\%) collected in traps within the Sacramento River basin emigrated as fry in both 2003 and 2004 (Fig. 6c,d). Although some juveniles from the federal hatchery could be collected in the lower Sacramento River trap, the observed size distribution of fish collected in that trap indicates that the catch consisted of primarily natural production (Fig. 6b versus Fig. 6d). Juveniles from the Mokelumne and Stanislaus Rivers displayed more even distributions of emigrant size classes (Fig. 6e,f).

Given the low proportion of hatchery fish released at fry sizes $(<2 \%)$, there is a high likelihood that the fry emigrants observed in the adult samples represent natural production. Additionally, there was greater natural production $(3 \times)$ above the Feather River trap in 2004 than 2003, which resulted in more fry-sized emigrants (Fig. 6c). Similarly, the mean estimate of total natural production upstream of a trap on lower Battle Creek was greater (2.8×) in 2004 than in 2003 (581 677 and 206266 juveniles in 2004 and 2003, respectively), and those catches comprised predominantly individuals $<40 \mathrm{~mm}$ FL (i.e. $>90 \%$ ). Given that the Feather River and Battle Creek are estimated to contribute nearly $50 \%$ of the total production in the Central Valley (Yoshiyama et al. 2000), it appears that fry production was greater in 2004 than in 2003. Despite this apparent interannual variation in production, fry emigrants made up an average of $20 \%$ of the adult sample in both years (Fig. 6a), which indicates potentially greater fry survival in 2003 than 2004. Furthermore, our data indicate that parr emigrants represent a greater proportion of the adult sample than the juvenile emigrant population (Fig. 6a versus Fig. 6b-f), potentially a result of in-river growth of fry emigrants or greater rates of survival for parr emigrants.

\section{DISCUSSION}

Quantifying the extent of phenotypic variation in juvenile migratory behavior is the initial step in understanding if, and how, such variation contributes to the resilience of managed populations. Examining the role of phenotypic variation in managed populations is an important component of effective conservation. This is particularly true within the highly modified Central Valley, where freshwater flows are often re-allocated during smolt emigration to improve survival under the assumption that smolts contribute disproportionately to the adult population (Brandes \& McLain 2001, Williams 2001). Additionally, studies examining survival of juveniles during migration through the riverine and Delta regions of the Central Valley focus on individuals $>75 \mathrm{~mm}$ FL, a result of using telemetry methods that require relatively large individuals (i.e. $>140 \mathrm{~mm}$ ) (Perry et al. 2010) or focusing on hatchery fish (Kimmerer 2008). In the present study, the relative proportions of the juvenile migratory phenotypes present within adult samples were similar across both years, and there was no clear evidence that smolt-sized emigrants contributed disproportionately to the adult 

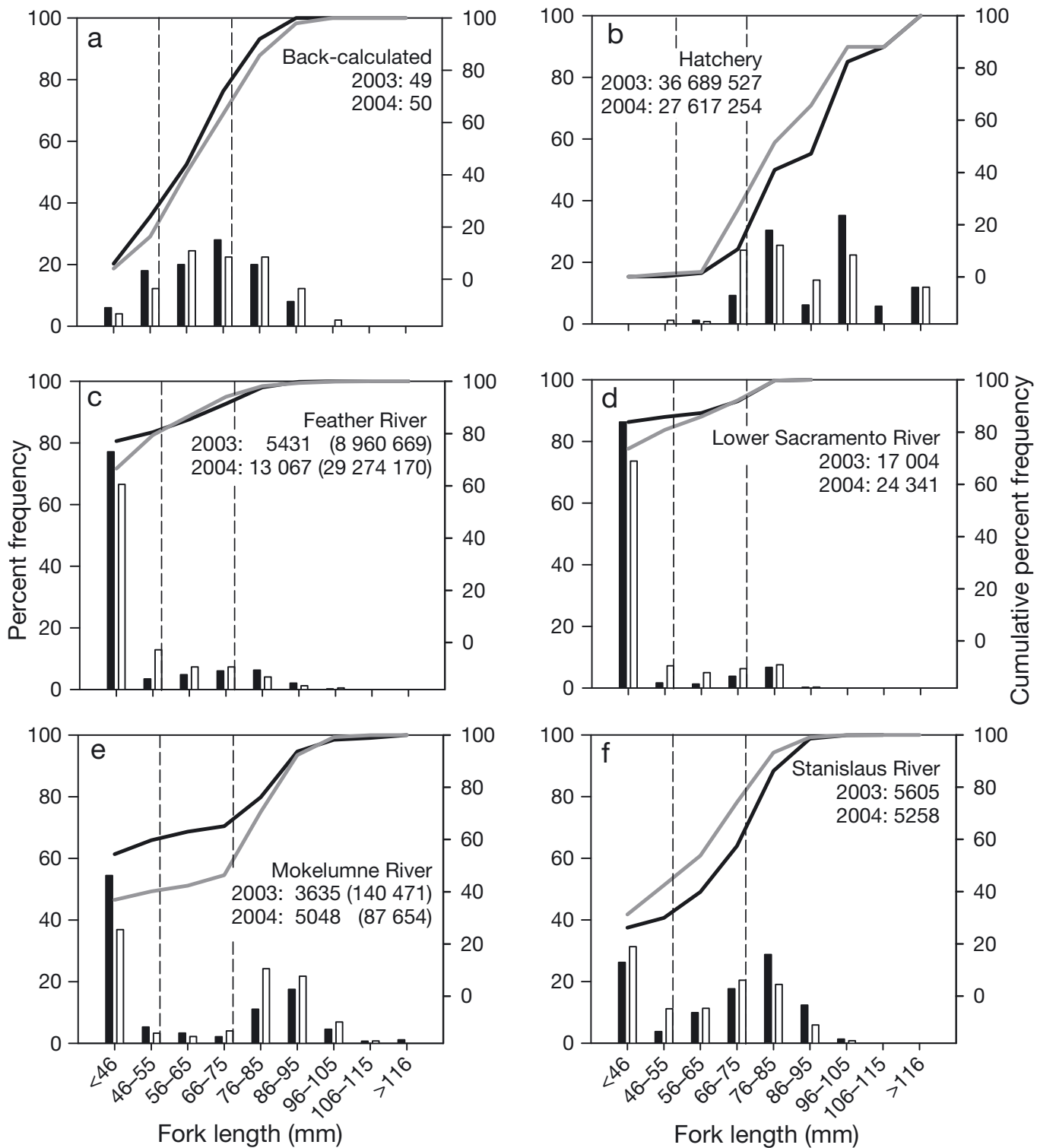

Fig. 6. Oncorhynchus tshawytscha. Size (fork length, $\mathrm{mm}$ ) frequency distributions (bars) and cumulative percent frequency of occurrence (solid lines) for Central Valley fall Chinook salmon emigrants. (a) Back-calculated size at freshwater emigration for adult fall Central Valley Chinook salmon as determined based on otolith structure and chemistry. (b) Size of hatchery-produced Chinook salmon upon release. (c-f) Size of primarily naturally produced Chinook salmon collected in rotary screw traps: (c) Feather, (d) Lower Sacramento, (e) Mokelumne, and (f) Stanislaus Rivers. The numbers of fish used to generate each distribution are included. For the Feather and Mokelumne River traps, estimates for the total number of individuals produced upstream of the trap are included $195 \%$ CI: Feather River in $2003=7158975$ to 13851505 and in $2004=20186009$ to 37851 505; Mokelumne River in $2003=95974$ to 310357

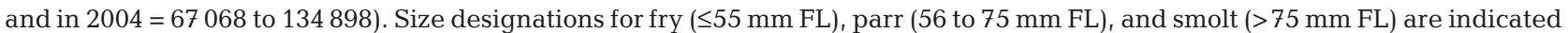

by dashed lines. Filled bars and black lines represent 2003 emigrants and open bars and grey lines represent 2004 emigrants

population. Furthermore, similar proportions of juvenile migratory phenotypes were observed in both years despite the fact that natural production was apparently lower in 2003 than 2004, which likely resulted in fewer fry emigrants. Although the relative survival of distinct migratory phenotypes appears to vary across years, these 3 phenotypes likely consistently contribute to adult production. The adult Central Valley fall Chinook salmon used in the present study were collected within the Oregon salmon troll fishery. Central Valley fall Chinook salmon have been captured consistently in the Oregon troll fishery (Weitkamp 2010); however, additional information on the juvenile migratory phenotypes represented in additional samples of Central Valley adult fall Chinook salmon, including those collected from other fishery locations and on spawning grounds, is needed to evaluate the consistency of the observed patterns. 
Although estuaries are known to provide rearing habitat for Chinook salmon (Reimers 1973, Healey 1991, Simenstad et al. 1982, Bottom et al. 2005, Volk et al. 2010), research in San Francisco Bay indicates that juvenile Chinook salmon may derive less benefit from estuarine residence than more northerly populations (MacFarlane \& Norton 2002). During the 1997 emigration, juvenile Chinook salmon (68 to $110 \mathrm{~mm}$ FL) resided in the estuary for an average of $40 \mathrm{~d}$ and grew relatively slowly (mean $\left.=0.18 \mathrm{~mm} \mathrm{~d}^{-1}\right)($ MacFarlane \& Norton 2002). Overall, their mean condition declined as they migrated through San Francisco Bay until they reached adjacent coastal waters where their growth rates accelerated (MacFarlane \& Norton 2002). These observations led to the supposition that 'the ecological and evolutionary propensity of emigrating juveniles to conform to a strong ocean-type life history, with little estuarine dependency and a hastened ocean entry, may be another unique attribute of Central Valley Chinook salmon' (MacFarlane \& Norton 2002, p. 255). However, MacFarlane \& Norton (2002) estimated growth based on change in mean size, which may be biased by size-dependent emigration and may in fact underestimate actual growth. Additionally, smaller fish, which may display different patterns of growth and residence, may have been under-represented in their mid-water trawl collections. The relative importance of estuarine rearing may vary across years with different environmental conditions. In the present study, a substantial proportion of the fish (40\%) entered brackish waters at sizes $<65 \mathrm{~mm}$ FL. Extended estuarine residence may be important for smaller fall Chinook salmon emigrants in the Central Valley.

Hatchery fish account for an estimated 17 to $90 \%$ of the total adult fall Chinook salmon production in the Central Valley (Kjelson et al. 1982, Yoshiyama et al. 1998, Yoshiyama et al. 2000, Barnett-Johnson et al. 2007). The relatively large range in estimates of hatchery contribution is due, in part, to challenges associated with accurately identifying hatchery fish and interannual variation in the hatchery contribution. However, given that most hatchery fish are released at sizes $>55 \mathrm{~mm}$ FL, it is likely that fry-sized emigrants observed in the present study represent natural production. Additional information on the origin of individual fish (hatchery versus naturally spawned) may be obtained through more detailed structural (Barnett-Johnson et al. 2007) or chemical $\left({ }^{34} \mathrm{~S}:{ }^{32} \mathrm{~S}\right.$, Weber et al. 2002) otolith analyses. Given the error rates associated with the identification of hatchery fish using structural analysis $(\sim 10 \%)$ and the instrumentation required for sulfur analysis (Weber et al. 2002), we did not incorporate either in the present study. Nonetheless, although fry-sized emigrants are consistently observed in lower rivers and estuaries (Collins 1892, Rich 1920, Reimers 1973), they remain a minor consideration in the Central Valley's water and salmon management practices (Brandes \& McLain 2001, Williams 2001). It is plausible that fry emigrants comprise a migratory contingent, i.e. a subpopulation aggregate that share common migratory pathways and thus experience differential survival compared with other contingents (Hjort 1914, Clark 1968, Secor 1999).

Theoretically, the presence of diverse juvenile migratory contingents provides resilience for a population that confronts varying environmental conditions (Thorpe et al. 1998, Secor 1999, Waples et al. 2009). However, as noted earlier, empirical evidence for the survival of distinct migratory variants within the Central Valley has been difficult to acquire. Survival estimates based on comparisons between juvenile and adult abundance are problematic because they are confounded by large variations in sampling efficiency. Tagging studies have been initiated in several Central Valley river systems to quantify the relative contribution of juvenile migratory phenotypes to adult populations. However, low production of naturally spawned juveniles, low recapture rates, and the 3 to 5 yr required to examine adult returns have prevented robust conclusions using this methodology. Analysis of the structural variation in scales has been used on a limited basis to provide information on the relative contribution of migratory phenotypes (Reimers 1973). However, these studies require extensive baseline development and are highly subjective; they are best suited to differentiating between individuals that emigrate from freshwater in their first year of life (sub-yearlings) or in their second year of life (yearlings), rather than among size classes within the sub-yearling life history. Approaches similar to ours can be applied to other diadromous species, at finer spatial scales (e.g. within rivers), and over a period of several years to further examine how successful juvenile migratory behaviors vary under different environmental conditions without the need to recapture individuals.

Our results indicate that a combined marker approach (otolith $\mathrm{Sr}: \mathrm{Ca}$ and $\mathrm{Ba}: \mathrm{Ca}$ ) holds promise for improving reconstructions of migratory history, but there are several factors to consider. For example, we observed that otolith Ba:Ca provided a slightly greater ability to differentiate residence in low salinity waters than otolith Sr:Ca in this species. However, by combining these 2 tracers, we were able to identify a pattern indicative of residence in brackish waters (i.e. otolith Sr:Ca > $1.5 \mathrm{mmol} \mathrm{mol}^{-1}$ and Ba:Ca $>2 \mu \mathrm{mol} \mathrm{mol}^{-1}$ ). More detailed examination of the temporal and spatial variation in water $\mathrm{Sr}: \mathrm{Ca}$ and Ba:Ca throughout San Francisco Bay and Delta during emigration may allow for more precise spatial determination of habitat use. Overall, the ability to reconstruct individual salinity history within a system largely depends on the freshwater Me:Ca values. Similar otolith chemical analyses 
in systems with greater freshwater Ba:Ca $(>600 \mu \mathrm{mol}$ $\left.\mathrm{mol}^{-1}\right)$ and/or lower $\mathrm{Sr}$ : Ca $\left(<4 \mathrm{mmol} \mathrm{mol}^{-1}\right)$ than the lower reaches of the Central Valley should provide additional salinity resolution (i.e. Volk et al. 2010).

For most populations of Chinook salmon, it is unclear how much variation in juvenile migratory behavior exists, how fluid that variation is, and whether survival varies among individuals with distinct migratory behaviors. Furthermore, it is not known if or how habitat modifications (such as the construction of dikes, levees, and bypass channels), freshwater discharge, harvest, and artificial propagation affect the relative proportion and survival of juvenile emigrants (but see Kimmerer 2008, Perry et al. 2010). As Healey (2009) notes, management strategies that enhance a dominant tactic (smolt-sized emigrants in this case) could reduce lifehistory diversity and result in a loss of population resilience. However, there is evidence that management practices can also result in the development of novel migratory phenotypes (i.e. a reservoir-rearing life history) (Connor et al. 2005). Lindley et al. (2009) indicate that hatchery production has reduced variation in juvenile size, condition, and migration timing in Central Valley fall Chinook salmon; they suggest that increased life-history diversity could reduce variability in adult production. The contribution of 3 juvenile migratory phenotypes to the Central Valley adult population indicates that a conservative management approach would focus on maintenance of life-history variation rather than the promotion of a particular phenotype.

Acknowledgements. The authors thank all participants of the Collaborative Research on Oregon Ocean Salmon (Project CROOS), particularly R. Bellinger and L. Borgerson, for their contributions and the Oregon Watershed Enhancement Board for funding. We appreciate the efforts of California's Interagency Ecological Program to maintain the rotary screw trap data collection program. We thank C. Zimmerman for data on water and otolith chemistry. C. A. 'Andy' Ungerer and A. Kent provided assistance with ICPMS. Support for J.A.M. was provided by Oregon State University's Coastal Oregon Experiment Station. Comments from C. A. Simenstad, S. Sogard, T. Hurst, L. Tomaro, and E. Backus and anonymous reviewers improved earlier versions of this manuscript. This effort is dedicated to the memory of S. Boley. This study was conducted in accordance with institutional, state, and national guidelines concerning the use of animals in research.

\section{LITERATURE CITED}

Barnett-Johnson R, Grimes C, Royer C, Donohoe C (2007) Identifying the contribution of wild and hatchery Chinook salmon (Oncorhynchus tshawytscha) to the ocean fishery using otolith microstructure as natural tags. Can J Fish Aquat Sci 64:1683-1692

Bottom DL, Jones KK, Cornwell TJ, Gray A, Simenstad CA (2005) Patterns of Chinook salmon migration and residency in the Salmon River estuary (Oregon). Estuar Coast Shelf Sci 64:79-93
Bottom DL, Jones KK, Simenstad CA, Smith CL (2009) Reconnecting social and ecological resilience in salmon ecosystems. Ecol Soc 14:5

> Bradbury IR, Campana SE, Bentzen P (2008) Otolith elemental composition and adult tagging reveal spawning site fidelity and estuarine dependency in rainbow smelt. Mar Ecol Prog Ser 368:255-268

Brandes PL, McLain JS (2001) Juvenile Chinook salmon abundance, distribution, and survival in the Sacramento-San Joaquin Estuary. In: Brown RL (ed) Contributions to the biology of Central Valley salmonids, Vol 2. Fish Bull 179: 39-138

Brown RJ, Severin KP (2009) Otolith chemistry analyses indicate that water $\mathrm{Sr}: \mathrm{Ca}$ is the primary factor influencing otolith Sr:Ca for freshwater and diadromous fish but not for marine fish. Can J Fish Aquat Sci 66:1790-1808

Campana SE (1999) Chemistry and composition of fish otoliths: pathways, mechanisms, and applications. Mar Ecol Prog Ser 188:263-297

Campana SE, Thorrold SR (2001) Otoliths, increments, and elements: Keys to a comprehensive understanding of fish populations? Can J Fish Aquat Sci 58:30-38

Chino N, Arai T (2009) Relative contribution of migratory type on the reproduction of migrating silver eels, Anguilla japonica, collected off Shikoku Island, Japan. Mar Biol 156:661-668

Clark J (1968) Seasonal movements of striped bass contingents of Long Island Sound and the New York Bight. Trans Am Fish Soc 97:320-343

Coffey M, Dehairs F, Collette O, Luther G, Church T, Jickells $\mathrm{T}$ (1997) The behaviour of dissolved barium in estuaries. Estuar Coast Shelf Sci 45:113-121

Colbert D, McManus J (2005) Importance of seasonal variability and coastal processes on estuarine manganese and barium cycling in a Pacific Northwest estuary. Cont Shelf Res 25:1395-1414

Collins JW (1892) Report of the fisheries of the Pacific Coast of the United States. US Comm Fish Fish 1888(Part XVI): $3-269$

Connor WP, Sneva JG, Tiffan KF, Steinhorst RK, Ross D (2005) Two alternative juvenile life history types for fall Chinook salmon in the Snake River basin. Trans Am Fish Soc 134: 291-304

Crook DA, Macdonald JI, Raadik TA (2008) Evidence of diadromous movements in a coastal population of southern smelts (Retropinninae: Retropinna) from Victoria, Australia. Mar Freshw Res 59:638-646

Daverat F, Tomas J, Lahaye M, Palmer M, Elie P (2005) Tracking continental habitat shifts of eels using otolith $\mathrm{Sr} / \mathrm{Ca}$ ratios: validation and application to the coastal, estuarine and riverine eels of the Gironde-Garonne-Dordogne watershed. Mar Freshw Res 56:619-627

Eaton AD, Clesceri LS, Rice EW, Greenberg AE (eds) (2005) Standard methods for the examination of water and wastewater. Port City Press, Baltimore, MD

> Elsdon TS, Gillanders BM (2003) Relationship between water and otolith elemental concentrations in juvenile black bream Acanthopagrus butcheri. Mar Ecol Prog Ser 260: 263-272

> Elsdon TS, Gillanders BM (2005) Alternative life-history patterns of estuarine fish: barium in otoliths elucidates freshwater residency. Can J Fish Aquat Sci 62:1143-1152

> Elsdon TS, Gillanders BM (2006) Identifying migratory contingents of fish by combining otolith Sr:Ca with temporal collections of ambient Sr:Ca concentrations. J Fish Biol 69: 643-657

Elsdon TS, Wells BK, Campana SE, Gillanders BM and others (2008) Otolith chemistry to describe movements and life- 
history measurements of fishes: hypotheses, assumptions, limitations, and inferences using five methods. Oceanogr Mar Biol Annu Rev 46:297-330

Gaetani GA, Cohen AL (2006) Element partitioning during precipitation of aragonite from seawater: a framework for understanding paleoproxies. Geochim Cosmochim Acta 70:4617-4634

Good TP, Waples RS, Adams P (2005) Updated status of federally listed ESUs of West Coast salmon and steelhead. NOAA Tech Memo NMFS-NWFSC-66, National Oceanic and Atmospheric Administration, Seattle, WA

Hamer PA, Jenkins GP, Coutin P (2006) Barium variation in Pagrus auratus (Sparidae) otoliths: a potential indicator of migration between an embayment and ocean waters in south-eastern Australia. Estuar Coast Shelf Sci 68:686-702

Healey MC (1991) Life history of Chinook salmon (Oncorhynchus tshawytscha). In: Groot C, Margolis L (eds) Pacific salmon life histories. UBC Press, Vancouver, p 313-393

Healey MC (2009) Resilient salmon, resilient fisheries for British Columbia, Canada. Ecol Soc 14:2

> Hedger RD, Atkinson PM, Thibault I, Dodson JJ (2008) A quantitative approach for classifying fish otolith strontium:calcium sequences into environmental histories. Ecol Inform 3:207-217

Hilborn R, Quinn TP, Schindler DE, Rogers DE (2003) Biocomplexity and fisheries sustainability. Proc Natl Acad Sci USA 100:6564-6568

Hjort (1914) Fluctuations in the great fisheries of Northern Europe. Rapp p-v Reun Cons Int Explor Mer 20:1-228

Holling CS (1973) Resilience and stability of ecological systems. Annu Rev Ecol Syst 4:1-23

Jefferts KB, Bergman PK, Fiscus HF (1963) A coded wire identification system for macro-organisms. Nature 198:460-462

Kimmerer WJ (2008) Losses of Sacramento River Chinook salmon and Delta smelt to entrainment in water diversions in the Sacramento-San Joaquin Delta. San Francisco Estuary and Watershed Science 6. Available at http:// escholarship.org/uc/item/7v92h6fs

Kjelson M, Raquel PF, Fisher FW (1982) Life history of fall run juvenile Chinook salmon Oncorhynchus tshawytscha in the Sacramento San Joaquin estuary, California, USA. In: Kennedy VS (ed) Estuarine comparisons. Academic Press, New York, NY, p 393-412

Kraus RT, Secor DH (2004) Incorporation of strontium into otoliths of an estuarine fish. J Exp Mar Biol Ecol 302:85-106

Limburg KE (1995) Otolith strontium traces environmental history of subyearling American shad Alosa sapidissima. Mar Ecol Prog Ser 119:25-35

Limburg KE (2001) Through the gauntlet again: demographic restructuring of American shad by migration. Ecology 82: 1584-1596

Lindley ST, Grimes CB, Mohr MS, Peterson W and others (2009) What caused the Sacramento River fall Chinook stock collapse? National Marine Fisheries Service, Southwest Fisheries Science Center. NOAA_TM_SWFSC-447, available at http://swr.nmfs.noaa.gov/media/Salmon DeclineReport.pdf

MacFarlane RB, Norton EC (2002) Physiological ecology of juvenile Chinook salmon (Oncorhynchus tshawytscha) at the southern end of their distribution, the San Francisco Estuary and Gulf of Farallones. Fish Bull 100:244-257

McCulloch M, Cappo M, Aumend J, Muller W (2005) Tracing the life history of individual barramundi using laser ablation MC-ICP-MS Sr-isotopic and Sr/Ba ratios in otoliths. Mar Freshw Res 56:637-644

Miller JA (2007) Scales of variation in otolith elemental chemistry of juvenile staghorn sculpin (Leptocottus armatus) in three Pacific Northwest estuaries. Mar Biol 151:483-494
Miller JA (2009) The effects of temperature and water concentration on the otolith incorporation of barium and manganese in black rockfish Sebastes melanops. J Fish Biol 75: $39-60$

Milton D, Halliday I, Sellin M, Marsh R, Staunton-Smith J, Woodhead J (2008) The effect of habitat and environmental history on otolith chemistry of barramundi Lates calcarifer in estuarine populations of a regulated tropical river. Estuar Coast Shelf Sci 78:301-315

Moyle PB (2002) Inland fishes of California. Revised and expanded. University of California Press, Berkeley, CA

Perry RW, Skalski JR, Brandes PL, Sandstrom PT, Klimley AP, Ammann A, MacFarlane RB (2010) Estimating survival and migration route probabilities of juvenile Chinook salmon in the Sacramento-San Joaquin River Delta. N Am J Fish Manag 30:142-156

Piper RG, McElwain IB, Orme LE, McCraren JP, Fowler LG, Leonard JR (1982) Fish health management. United States Department of the Interior, Fish and Wildlife Service, Washington, DC

Quinn TP (2005) The behavior and ecology of Pacific salmon and trout. University of Washington Press, Seattle, WA

Reimers PE (1973) The length of residence of juvenile fall Chinook salmon in Sixes River, Oregon. Research Reports of the Fish Commission of Oregon. Oregon Department of Fish and Wildlife, Corvallis, OR, p 1-42

Rich WH (1920) Early life history and seaward migration of Chinook salmon in the Columbia and Sacramento Rivers. Fish Bull 37:1-73

Secor DH (1999) Specifying divergent migrations in the concept of stock: the contingent hypothesis. Fish Res 43:13-34

Secor DH (2007) The year-class phenomenon and the storage effect in marine fishes. J Sea Res 57:91-103

Secor DH, Henderson-Arzapalo A, Piccoli PM (1995) Can otolith microchemistry chart patterns of migration and habitat utilization in anadromous fishes? J Exp Mar Biol Ecol 192:15-33

Seeb LW, Antonovich A, Banks MA, Beacham TD and others (2007) Development of a standardized DNA database for Chinook salmon. Fisheries 32:540-552

Simenstad CA, Fresh KL, Salo EO (1982) The role of Puget Sound and Washington coastal estuaries in the life history of Pacific salmon: an unappreciated function. In: Kennedy VS (ed) Estuarine comparisons. Academic Press, New York, NY, p 343-364

Stearns SC (1992) The evolution of life histories. Oxford University Press, New York, NY

> Swart PK, Healy G, Greer L, Lutz M and others (1999) The use of proxy chemical records in coral skeletons to ascertain past environmental conditions in Florida Bay. Estuaries 22: 384-397

Taylor EB (1990) Environmental correlates of life-history variation in juvenile Chinook salmon, Oncorhynchus tshawytscha (Walbaum). J Fish Biol 37:1-17

Thibault I, Dodson JJ, Caron F, Tzeng WN, Iizuka Y, Shiao JC (2007) Facultative catadromy in American eels: testing the conditional strategy hypothesis. Mar Ecol Prog Ser 344: 219-229

Thorpe JE, Mangel M, Metcalfe NB, Huntingford FA (1998) Modelling the proximate basis of salmonid life-history variation, with application to Atlantic salmon, Salmo salar L. Evol Ecol 12:581-599

> Volk EC, Bottom DL, Jones KK, Simenstad CA (2010) Reconstructing juvenile Chinook salmon life history in the Salmon River estuary, Oregon, using otolith microchemistry and microstructure. Trans Am Fish Soc 139:535-549

Waples RS, Beechie T, Pess GR (2009) Evolutionary history, habitat disturbance regimes, and anthropogenic changes: 
What do these mean for resilience of Pacific salmon populations? Ecol Soc 14:3

Weber PK (2002) Geochemical markers in the otoliths of Chinook salmon in the Sacramento-San Joaquin River system, California. PhD dissertation, University of California, Berkeley, CA

Weber PK, Hutcheon ID, McKeegan KD, Ingram BL (2002) Otolith sulfur isotope method to reconstruct salmon (Oncorhynchus tshawytscha) life history. Can J Fish Aquat Sci 59:587-591

Wei GJ, Sun M, Li XH, Nie BF (2000) Mg/Ca, Sr/Ca and U/Ca ratios of a Porites coral from Sanya Bay, Hainan Island, South China Sea and their relationships to sea surface temperature. Palaeogeogr Palaeoclimatol Paleoecol 162:59-74

Weitkamp LA (2010) Marine distributions of Chinook salmon from the west coast of North America determined by coded wire tag recoveries. Trans Am Fish Soc 139:147-170

Williams JG (2001) Chinook salmon in the lower American River, California's largest urban stream. In: Brown RL (ed) Contributions to the biology of Central Valley salmonids, Vol 2. Fish Bull 179:1-38

> Yoshiyama RM, Fisher FW, Moyle PB (1998) Historical abundance and decline of Chinook salmon in the Central Valley Region of California. N Am J Fish Manag 18:487-521

Yoshiyama RM, Gerstung ER, Fisher FW, Moyle PB (2000) Chinook salmon in the Central Valley: an assessment. Fisheries 25:6-20

Zar JH (1999) Biostatistical analysis, 4th edn. Prentice Hall, New Jersey

Zimmerman CE (2005) Relationship of otolith strontium-tocalcium ratios and salinity: experimental validation for juvenile salmonids. Can J Fish Aquat Sci 62:88-97

\section{Appendix 1. Additional data on water and otolith chemistry}

Table A1. Water Sr:Ca $\left(\mathrm{mmol} \mathrm{mol}^{-1}\right)$ and $\mathrm{Ba}: \mathrm{Ca}\left(\mu \mathrm{mol} \mathrm{mol}{ }^{-1}\right)$ and predictions for Chinook salmon otolith $\mathrm{Sr}: \mathrm{Ca}\left(\mathrm{mmol} \mathrm{mol}^{-1}\right)$ and Ba:Ca $\left(\mu \mathrm{mol} \mathrm{mol}{ }^{-1}\right)$. Data from Weber (2002) were collected monthly from October 1997 to September 1999; data from C. E. Zimmerman (unpubl. data) were collected in March, July, and November in 2003-2005; National Stream Quality Accounting Network (NASQAN; http://water.usgs.gov/nasqan/) data were collected approximately monthly from 1973-1995 (n = 46); and samples were collected in February 2008 for the present study. Predicted otolith Me:Ca ratios were based on observed otolith and water Me:Ca ratios (see 'Results' for details). For water Me:Ca, Weber $(2002)=$ median values; all others $=$ mean values \pm SD. For predicted otolith $\mathrm{Me}: \mathrm{Ca}, 95 \% \mathrm{CI}$ are presented in parentheses. nd: no data available

\begin{tabular}{|c|c|c|c|c|c|}
\hline Location & $\begin{array}{l}\text { Water Sr:Ca } \\
\left(\mathrm{mmol} \mathrm{mol}^{-1}\right)\end{array}$ & $\begin{array}{l}\text { Water Ba:Ca } \\
\left(\mu \mathrm{mol} \mathrm{mol}^{-1}\right)\end{array}$ & $\begin{array}{l}\text { Predicted otolith } \\
\text { Sr:Ca }\left(\mathrm{mmol} \mathrm{mol}^{-1}\right)\end{array}$ & 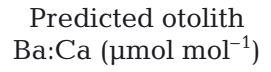 & Source \\
\hline Sacramento River & 2.41 & 408 & $0.91(0.17)$ & $4.51(0.36)$ & Weber (2002) \\
\hline Upper Sacramento River & $3.00(0.75)$ & nd & $0.93(0.15)$ & nd & $\begin{array}{l}\text { C. E. Zimmerman } \\
\text { (unpubl. data) }\end{array}$ \\
\hline Battle Creek & 3.99 & 417 & $1.00(0.12)$ & $4.58(0.37)$ & Weber (2002) \\
\hline Mill Creek & 3.42 & 288 & $0.95(0.13)$ & $3.59(0.34)$ & Weber (2002) \\
\hline Deer Creek & 3.47 & 709 & $0.96(0.13)$ & $6.83(0.53)$ & Weber (2002) \\
\hline Upper Deer Creek & $3.66(0.75)$ & nd & $0.97(0.13)$ & nd & $\begin{array}{l}\text { C. E. Zimmerman } \\
\text { (unpubl. data) }\end{array}$ \\
\hline Butte Creek & 2.76 & 141 & $0.92(0.15)$ & $2.47(0.35)$ & Weber (2002) \\
\hline Feather River & 3.07 & 440 & $0.93(0.14)$ & $4.76(0.38)$ & Weber (2002) \\
\hline Feather River Hatchery & 3.18 & 446 & $0.94(0.14)$ & $4.81(0.38)$ & Weber (2002) \\
\hline American River & 3.41 & 584 & $0.95(0.13)$ & $5.87(0.45)$ & Weber (2002) \\
\hline American River Hatchery & 3.61 & 618 & $0.96(0.13)$ & $6.13(0.47)$ & Weber (2002) \\
\hline Upper Yuba River & $2.89(0.38)$ & nd & $0.93(0.15)$ & nd & $\begin{array}{l}\text { C. E. Zimmerman } \\
\text { (unpubl. data) }\end{array}$ \\
\hline Northern Delta & 3.94 & 595 & $0.99(0.12)$ & $5.95(0.45)$ & Weber (2002) \\
\hline Southern Delta & 5.36 & 514 & $1.18(0.09)$ & $5.33(0.41)$ & Weber (2002) \\
\hline Mokelumne River & 4.92 & 1140 & $1.11(0.10)$ & $10.15(0.86)$ & Weber (2002) \\
\hline Mokelumne River Hatchery & 5.15 & 1168 & $1.14(0.10)$ & $10.37(0.88)$ & Weber (2002) \\
\hline Tuolumne River & 3.75 & 708 & $0.98(0.13)$ & $6.82(0.53)$ & Weber (2002) \\
\hline Tuolumne River & $3.96(0.97)$ & nd & $0.99(0.12)$ & nd & $\begin{array}{l}\text { C. E. Zimmerman } \\
\text { (unpubl. data) }\end{array}$ \\
\hline Merced River & 3.21 & 1606 & $0.94(0.14)$ & $13.74(1.25)$ & Weber (2002) \\
\hline Upper Merced River & $4.03(0.57)$ & nd & $1.00(0.12)$ & nd & $\begin{array}{l}\text { C. E. Zimmerman } \\
\text { (unpubl. data) }\end{array}$ \\
\hline Merced River Hatchery & 3.32 & 1679 & $0.95(0.14)$ & $14.30(1.31)$ & Weber (2002) \\
\hline Upper Calaveras River & $3.16(0.55)$ & nd & $0.94(0.14)$ & nd & $\begin{array}{l}\text { C. E. Zimmerman } \\
\text { (unpubl. data) }\end{array}$ \\
\hline Upper Stanislaus River & $4.51(0.39)$ & nd & $1.05(0.11)$ & nd & $\begin{array}{l}\text { C. E. Zimmerman } \\
\text { (unpubl. data) }\end{array}$ \\
\hline San Joaquin River at Vernalis & $5.30(0.08)$ & $425(5)$ & $1.17(0.10)$ & $4.64(0.37)$ & NASQAN \\
\hline Lower Cosumnes River & $3.54(0.08)$ & $747(61)$ & $0.96(0.13)$ & $7.12(0.55)$ & Present study \\
\hline Lower Mokelumne River & $5.37(0.06)$ & $1622(6)$ & $1.18(0.10)$ & $13.86(1.26)$ & Present study \\
\hline Lower Calaveras River & $2.56(0.10)$ & $524(144)$ & $0.92(0.16)$ & $5.40(0.41)$ & Present study \\
\hline Stanislaus River & $4.10(0.12)$ & $698(52)$ & $1.01(0.12)$ & $6.74(0.52)$ & Present study \\
\hline Lower San Joaquin River & $5.48(0.04)$ & $468(8)$ & $1.20(0.10)$ & $4.97(0.39)$ & Present study \\
\hline Coastal ocean & $8.55(0.33)$ & $5.03(1.08)$ & $1.98(0.13)$ & $1.41(0.40)$ & Present study \\
\hline
\end{tabular}

